\title{
F508 amino acid deletion mutation of CFTR gene in Korean lung cancer patients
}

\author{
Yunyoung Jung ${ }^{1 *}$, Hongil $\mathrm{Ha}^{1 *}$, Soon-Hee Jung ${ }^{2}$ \\ Min Goo Lee ${ }^{3}$, Hyean-Woo Lee ${ }^{1}$, Joonho Yoon ${ }^{1}$, \\ Jong-Whan Choi ${ }^{1}$ and Byung-II Yeh ${ }^{1,4}$
${ }^{1}$ Department of Biochemistry and Institute of Basic Medical Science, Wonju College of Medicine, Yonsei University, Wonju 220-701, Korea
${ }^{2}$ Department of Pathology, Wonju College of Medicine, Yonsei University, Wonju 220-701, Korea
${ }^{3}$ Department of Pharmacology, College of Medicine, Yonsei University, Seoul 120-752, Korea
${ }^{4}$ Corresponding author: Tel, +82-33-741-0282;
Fax, +82-33-743-0411; E-mail, mia1 @ wonju.yonsei.ac.kr
"These authors contributed equally to the work.

Accepted 3 March, 2001

Abbreviations: CFTR, cystic fibrosis transmembrane conductance regulator; RT-PCR, reverse transcription-polymerase chain reaction; DEPC, diethylpyrocarbonate; CF, cystic fibrosis

\begin{abstract}
Mutations of the transmembrane conductance regulator (CFTR) gene in cystic fibrosis lead to dysfunction of the lung, pancreas, and sweat glands, etc. To investigate the possibility of the relationship between lung cancer and the mutations of CFTR gene, we determined amino acid sequences using reverse transcription-polymerase chain reaction (RT-PCR) and DNA sequencing. In this study, the deletion mutation of 508th amino acid in one of nine lung caner patients was found confirming that CFTR gene mutation exists in a Korean lung cancer patient.
\end{abstract}

Keywords: CFTR, mutation, lung cancer

\section{Introduction}

Cystic fibrosis is a severe autosomal recessive genetic disorder affecting approximately 1 in 2,500 live births in the Caucasian population (Boat et al., 1989). This disease invades a number of organs, including the lung, pancreas, and sweat glands (Boat et al., 1989), and is characterized by recurrent pulmonary infections, impaired pulmonary function, and disseminated bronchiectasis. Transmembrane conductance regulator (CFTR) gene identified at chromo- some 7 (Kerem et al., 1989; Riordan et al., 1989; Rommens et al., 1989) is known to be responsible for cystic fibrosis, and a variety of mutations of CFTR gene have been identified (Xu and Gruenert, 1996; Sharer et al., 1998; Cohn et al., 1998).

Most frequent mutation in CFTR gene is 508th amino acid deletion and found in many diseases, including chronic pancreatitis (Cohn et al., 1998; Sharer et al., 1998), disseminated bronchiectasis (Pignatti et al., 1995), bronchopulmonary aspergillosis (Weiner et al., 1996), chronic bronchitis, and pulmonary emphysema (Bombieri et al., 1998), etc. However, cystic fibrosis is not a common disease in Asian and only one case has been reported in a Korean male infant with recurrent bronchitis. (Moon $\mathrm{HR}$ et al., 1988) It appears that there exists genetic characteristics among races.

In addition, CFTR gene mutation is found in pulmonary and breast cancer patients (Southey et al., 1998), and it is hypothesized that CFTR gene may be related to cancer pathogenesis (Tien et al., 1994). In this study, the analysis of CFTR gene in Korean lung cancer patients was made.

\section{Materials and Methods}

\section{Specimens}

In this experiment, samples were collected from patients who had been admitted to Wonju Christian Hospital in Korea. Nine patients with lung cancer on Histological examination particulated in this study.

\section{RT-PCR (reverse transcription-polymerase chain reaction)}

RNAs were extracted from cancer tissues by using RNaid kit (BIO 101, Vista, CA, USA). After ethanol precipitation, each RNA pellet was dissolved in $10 \mu \mathrm{L}$ of DEPC (diethylpyrocarbonate)-treated distilled water and used for cDNA preparation.

cDNA synthesis was performed as described previously by Han et al. (2000). Two $\mu \mathrm{L}$ of purified RNA was reverse transcribed for $1 \mathrm{~h}$ at $42^{\circ} \mathrm{C}$ with 10 units of avian myeloblastosis virus reverse transcriptase, $2 \mu \mathrm{L}$ of $10 \times$ reaction buffer $(100 \mathrm{mM}$ Tris- $\mathrm{HCl} \mathrm{pH} 8.8,500 \mathrm{mM} \mathrm{KCl}$, and $1 \%$ Triton $\mathrm{X}-100), 15$ units of RNasin, $1 \mu \mathrm{g}$ of oligo (dT) primer, $1 \mu \mathrm{L}$ of $10 \mathrm{mM}$ dNTP mix, and $2 \mu \mathrm{L}$ of $25 \mathrm{mM}$ magnesium chloride.

The cDNAs obtained by reverese transcription were amplified by PCR. The primer sequences for PCR were 5'-ACTGGAGCCTTCAGAGGGTA-3' for forward primer, and 5'-TGGCATGCTTTGATGACGCT-3' for backward 
primer, respectively. PCR was performed in $20 \mu \mathrm{L}$ of reaction volume containing $10 \mathrm{mM}$ Tris- $\mathrm{HCl}(\mathrm{pH}$ 8.3), 50 $\mathrm{mM}$ potassium chloride, $2.5 \mathrm{mM}$ magnesium chloride, $0.01 \%$ gelatin, 10 pmole of each primer, $100 \mu \mathrm{M}$ of each deoxyribonucleotide triphosphates, and 1 unit of Taq DNA polymerase. The reaction was carried out using the modified method described by Saiki et al. (1988) in a Mini Cycler ${ }^{\mathrm{TM}}$ (MJ Research Inc., Watertown, MA, USA). Before cycling reaction, reaction tube was incubated at $94^{\circ} \mathrm{C}$ for $5 \mathrm{~min}$ to denature completely, and 30 cycling reactions were performed to amplify target sequences. Each reaction cycle included denaturation at $94^{\circ} \mathrm{C}$ for 30 $\mathrm{s}$, primer annealing at $55^{\circ} \mathrm{C}$ for $30 \mathrm{~s}$ and primer extension at $72^{\circ} \mathrm{C}$ for $30 \mathrm{~s}$.

PCR products were subjected to agarose gel electrophoresis in Tris-acetate-EDTA buffer and visualized in the presence of ethidium bromide under ultraviolet transillumination.

\section{DNA Sequencing}

Amplified cDNAs were isolated from agarose gel and purified with DNA PrepMateTM (Bioneer, Chungwon, Korea). They were then subcloned by inserting the cDNA into a pGEM T-vector (Amersham Pharmacia Biotech., Uppsala, Sweden). Plasmids containing cDNA of CFTR were selected by $\alpha$-complementation.

After growing the colonies, plasmid DNA was purified by using the modified method of Sambrook et al. (1989). DNA sequencing was performed by using the modified method of Sanger's dideoxy method (1978). A T7 DNA Polymerase Sequencing kit (Amersham Pharmacia Biotech., Sweden) was used for this process.

\section{Clinical Findings}

The clinical characteristics of nine patients were recorded on the basis of their clinical records.

\section{Results and Discussion}

The characteristics of nine patients used in this study

were shown in Table 1. Patient No. 9 with adenocarcinoma of the lung was readmitted because squamous cell carcinoma was developed after left pneumonectomy and radical lymph node dissection. Patients No. 2 and No. 6 had anemia and pneumonia, respectively, and another six patients had no pertinent findings.

In the present study, a $\Delta \mathrm{F} 508$ mutation was found in a Korean lung cancer patient on the basis of cDNA sequencing from 455th to 525th amino acid of CFTR protein. As shown in Figure 1, a F508 deletion of CFTR gene was appeared in patient No. 6. This is the first report of a mutated CFTR gene in Korean population. This case is thought to be a heterozygote because we could confirm four deletion mutations and two normal sequences among six clones (data not shown).

Among more than 900 kinds of CFTR gene mutations, $\Delta \mathrm{F} 508$ is the most prevalent type. In normal Caucasian population, prevalence of heterozygote $\Delta \mathrm{F} 508$ mutation can be reached up to $1.8 \%$ (Southery et al., 1998). Therefore, it is difficult to assume that $\Delta \mathrm{F} 508$ mutation is associated with the pathogenesis of lung cancer. However, the presence of $\Delta \mathrm{F} 508$ mutation in Korean population was a surprising result, since there was only one

A
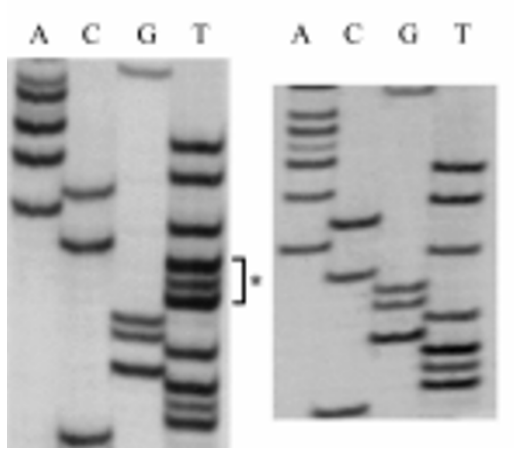

Figure 1. cDNA sequences around 508th amino acid of CFTR. * indicate the location of 508th amino acid (TTT). Panels $A$ and $C$ show normal sequences but panel $B$ shows $\triangle F 508$ (TTT) mutant. Panels $A, B, C$ correspond to patients No. 1, No. 6, No. 9 in Table 1, respectively.

Table 1. Clinical characteristics of nine lung cancer patients

\begin{tabular}{|c|c|c|c|c|c|c|}
\hline No. & Age & Sex & Pathologic diagnosis & Stage & $\begin{array}{c}\text { Accompanying } \\
\text { disease }\end{array}$ & Smoking History \\
\hline 1 & 59 & M & squamous cell carcinoma & IB & none & 2 pack/day $\times 40$ years \\
\hline 2 & 42 & M & adenocarcinoma & IIB & anemia & none \\
\hline 3 & 68 & M & squamous cell carcinoma & IIIA & none & 1 pack/day x 40 years \\
\hline 4 & 43 & $\mathrm{~F}$ & adenocarcinoma with signet ring cell carcinoma & IIIA & none & none \\
\hline 5 & 71 & M & adenocarcinoma & IIIA & none & 1 pack/day x 40 years \\
\hline 6 & 27 & $\mathrm{~F}$ & bronchoalveolar carcinoma & IB & pneumonia & none \\
\hline 7 & 44 & M & small cell carcinoma & extensive & none & 2-3 pack/day $\times 20$ years \\
\hline 8 & 61 & M & squamous cell carcinoma & IB & none & 1 pack/day x 40 years \\
\hline 9 & 60 & M & adenocarcinoma & IIIB & $\begin{array}{l}\text { squamous cell } \\
\text { carcinoma }\end{array}$ & 2-3 pack/day x 20 years \\
\hline
\end{tabular}


presumptive report of cystic fibrosis (CF) in Korea (Moon et al., 1988).

We analyzed 13 cDNA samples from 9 cancer patients and 4 normal lung tissues and $\triangle F 508$ CFTR gene was found only in one lung cancer patient. Although the sample size were is small, our results suggest two possibilities. First, there may exist a considerable rate of CFTR gene mutation in Korean population even though a typical CF presentation is rare. Recent studies revealed that the mutation in CFTR gene is not only associated with CF but also associated with many other epithelial disorders such as bronchiectasis, chronic bronchitis, and chronic pancreatitis. Considering the fact that epithelial disorders are also common in Korean population, a more large scale study searching for CFTR gene mutation is urgently needed. Second, the mutation in CFTR gene may be correlated with the lung cancer. Although this assumption is quite speculative, there are some supportive evidences. CFTR gene is needed for apoptosis in epithelial cells and mutated CFTR gene in epithelial cells loses their apoptotic control (Gottlieb, and Dosanjh. 1996). Indeed, Bombieri et al. (1998) found four different kinds of mutations in 26 lung cancer patients but there was no $\Delta \mathrm{F} 508$ deletion mutant although it also needs a further verification by a large scale study.

In this study, the first case of CFTR gene mutation in a Korean lung cancer patient is reported. This No. 6 patient with left lower lobectomy for bronchoalveolar carcinoma was 27 years old and had chronic pneumonia for more than three years which was treated with antibiotics. A further, large scale study in Korean lung cancer patients as well as in normal populations is needed to identify the role of CFTR gene mutation.

\section{Acknowledgement}

This work was supported by student's research fund of Wonju College of Medicine, Yonsei University, in 1999.

\section{References}

Boat, T. F., Welsh, M. J. and Beaudet, A. L. (1989) Cystic Fibrosis. In the Metabolic Basis of the Disease (Server, C. L. et al. eds.), pp. 2649-2680, McGraw-Hill, New York

Bombieri, C., Benetazzo, M., Xaccomani, A., Belpinati, F., Gil, L. S., Luisetti, M. and Pignatti, P. F. (1998) Complete mutational screening of the CFTR gene in 120 patients with pulmonary disease. Hum. Genet. 103: 718-722

Cohn, J. A., Friedman, K. J., Noone, P. G., Knowles, M. R., Silverman, L. M. and Jowell, P. S. (1998) Relation between mutations of the cystic fibrosis gene and idiopathic pancreatitis. New. Engl. J. Med. 339: 653-658

Gottlieb, R. A. and Dosanjh, A. (1996) Mutant cystic fibrosis transmembrane conductance regulator inhibits acidification and apoptosis in C127 cells: possible relevance to cystic fibrosis. Proc. Natl. Acad. Sci. (USA) 93: 3587-3591

Han, D.-P., Lee, H.-Y., Sohn, J. H., Yeh, B.-I., Choi, J.-W. and Kim, H.-W. (2000) The new genotypic human calicivirus isolated in Seoul. Exp. Mol. Med. 32: 6-11

Kerem, B., Rommens, J. M., Buchanan, J. A., Markiewicz, D., Cox, T. K., Chakravarti, A. and Tsui, L.-C. (1989) Identification of the cystic fibrosis gene: genetic analysis. Science 245: 1073-1080

Moon, H. R., Ko, T. S., Ko, Y. Y., Choi, J. H. and Kim, Y. C. (1988) Cystic fibrosis-a case presented with recurrent bronchiolitis in infancy in a Korean male infant. J. Korean Med. Sci. 3: $157-162$

Pignatti, P. F., Bombieri, C., Marigo, C., Benetazzo, M. G. and Luisetti, M. (1995) Increased incidence of cystic fibrosis gene mutations in adults with disseminated bronchiectasis. Hum Mol. Genet. 4: 635-639

Riordan, J. R., Rommens, J. M., Kerem, B., Alon, N., Rozmahel, R., Grzelezak, Z., Zielenski, J., Lok, S., Plavsic, N., Chou, J.-L., Drumm, M., lannuzzi, M. C., Collins, S. F. and Tsui L.-C. Identification of the cystic fibrosis gene: cloning and characterization. Science 245: 1066-1073

Rommens, J. M., lannuzzi, M. C., Collins, S. F. and Tsui, L.C. (1989) Identification of the cystic fibrosis gene: chromosome walking and jumping. Science 245: 1059-1065

Saiki, R. K., Gelfand, D. H., Stoffel, S., Scharf, S. V., Higchi, R., Horn, G. T., Mullis, K. and Ehrlich, H. A. (1988) Primer directed enzymatic amplification of DNA with a thermostable DNA polymerase. Science 239: 487-491

Sambrook, J., Fritsch, E. F. and Maniatis, T. (1989) Plasmid vector: Extraction and purification of plasmid DNA. In Molecular cloning. A laboratory manual. (Sambrook et al. eds.) pp. 1.21-1.51, Cold Spring Habor Laboratory press, New York

Sanger, F. and Coulson, A. R. (1978) The use of thin acrylamide gels for DNA sequencing. FEBS Lett 87: 107-110

Sharer, N., Schwarz, M., Malone, G., Howarth, A., Painter, J., Super, M. and Braganza, J. (1998) Mutations of the cystic fibrosis gene in patients with chronic pancreatitis. New. Engl. J. Med. 339: 645-652

Southey, M. C., Batten, L., Andersen, C. R., McCredie, M. R., Giles, G. G., Dite, G., Hopper, J. L. and Venter, D. J. (1998) CFTR $\Delta$ F508 carrier status, risk of breast cancer before the age of 40 and histological grading in a population-based casecontrol study. Int. J. Cancer 79: 487-489

Tien, S. Y., Brasitus, T. A., Kaetzel, M. A., Dedman, J. R. and Nelson, D. J. (1994) Activation of the cystic fibrosis transmembrane conductance regulator by CGMP in the human colonic cancer cell line, Caco-2. J. Biol. Chem. 269: 51-54

Weiner, M. P., Hamosh, A., Macek, M., Greenberger, P. A., MacLean, J., Walden, S. M., Slavin, R. G. and Cutting, G. R. (1996) Cystic fibrosis transmembrane conductance regulator (CFTR) gene mutations in allergic bronchopulmonary aspergillosis. Am. J. Hum. Genet. 59: 45-51

Xu, Z. and Gruenert, D. C. (1996) Human CFTR gene sequences in regions flanking exon 10: a simple repeat sequence polymorphism in intron 9. Biochem. Biophys. Res. Commun. 219: 140-145 